\title{
DAMPAK MANISAN TERHADAP EKONOMI masYarakat dI KabUPATEN GIANJUR
}

\author{
The Impact of Pickles to People's Economy in Cianjur
}

\author{
Oleh Enden Irma Rachmawaty \\ Balai Pelestarian Nilai Budaya Bandung \\ Jl. Cinambo No.136 Telp./Fax (022) 7804942 Ujung Berung - Bandung 42094
}

Naskah Diterima: 27 Juli 2012

Naskah Disetujui:28 Agustus 2012

\begin{abstract}
Abstrak
Di setiap daerah pasti mempunyai menu makanan khas sendiri, menu makanan khas ini timbul dari lingkungannya sendiri, dan dapat dipastikan tidak diketahui asal mula pembuatnya, yang pasti pembuatan menu makanan tersebut merupakan warisan yang turun temurun, begitu juga dengan pengrajin makanan khas Cianjur. Pengrajin makanan khas Cianjur bukan hanya buah-buahan sebagai bahan pokok pembuatan manisan, tetapi bisa juga dari bahan pokok sayuran. Ada beberapa yang termasuk kedalam makanan khas Cianjur, di antaranya adalah Manisan Sayuran Sawi. Manisan Kedondong, Manisan Canar, Manisan Salak, Manisan Rumput Laut, Manisan Jambu Biji, Manisan Pala, dan lain-lain. Pada awalnya semua jenis makanan khas Cianjur merupakan konsumsi masyarakat dengan status sosial menengah kebawah, tetapi pada saat ini semua jenis makanan khas Cianjur tersebut sudah merupakan konsumsi semua lapisan masyarakat. Hal ini ditandai bukan hanya dijual di toko-toko tetapi sudah masuk ke supermarketsupermarket yang ada di Cianjur, bahkan banyak juga yang memakai sebagai menu pelengkap dalam rangka hajatan di hotel-hotel berbintang. Alasan dilakukannya penelitian ini adalah sebagai upaya untuk mendapatkan informasi yang lebih dalam tentang manisan Cianjur. Penelitian ini menggunakan metode deskriptif dan metoda wawancara. Hasil dari penelitian ini menunjukan bahwa manisan Cianjur cukup mengalami perkembangan baik dari segi bahan maupun pemanfatannya.
\end{abstract}

Kata Kunci: Pengrajin Makanan Khas, Cianjur.

\begin{abstract}
Every region has its own typical food that has been developed within its society and no one knows who made it first. The fact is that it is inherited from one generation to another. This also happens to artisan food of Cianjur who make manisan (pickles) of fruits and vegetables. Formerly the pickles were consumed by middle to lower class in the society, but it gradually becomes popular to everyone. This kind of food can be found either in small shops or supermarkets. Hotels serve them as desserts. This research seeks
\end{abstract}


more detailed information about pickles of Cianjur by using descriptive method and interviews. The result shows that pickles from Cianjur have been developing very well.

Keywords: food artisan of typical food, Cianjur

\section{A. PENDAHULUAN}

Tiap masyarakat memiliki kebudayaan yang hidup dalam komunitas wilayahnya, kebudayaan dapat menampilkan suatu corak khas yang dapat dilihat oleh masyarakat luar bahkan oleh masyarakat yang bersangkutan. Kebiasaan-kebiasaan yang terpelihara dan dijunjung tinggi mengandung nilai-nilai yang luhur, yang kemudian merupakan unsur kebudayaan yang dihayati oleh seluruh masyarakat pendukungnya. Karena biasanya nilai-nilai yang terkandung di dalamnya banyak berkaitan dengan sistem kepercayaan pada masyarakat setempat.

Perubahan-perubahan kebudayaan akan menyebabkan terjadinya pergeseran nilai, gagasan yang di satu pihak punahnya sistem ekonomi tradisional yang lama dan dilain pihak timbulnya sistem ekonomi baru dengan nilai dan gagasan baru. Pergeseran yang terjadi, menggugah kita untuk mengetahui sampai sejauh mana peranan kebudayaan didalam sistem ekonomi tradisional.

Salah satu bentuk dari kebudayaan yang masih hidup itu adalah kerajinan. Dalam kehidupan masyarakat, khususnya masyarakat Jawa Barat, kebudayaannya sangat banyak dan sangat beragam, baik bentuk, jenis maupun cara penyajiannya. Hal ini terlihat dari keberadaan berbagai macam kerajinan di masyarakat.

Keberadaan kerajinan tradisional pada masyarakat, khususnya pada saat ini umumnya kurang begitu menarik perhatian. Masyarakat lebih tertarik pada hasil karya bangsa asing. Kenyataan ini berdampak luas pada keberadaan makanan tradisional yang berdampak pada terkikisnya nilai-nilai budaya dan ekonomi.

Jawa Barat salah satu provinsi di Indonesia yang cukup kaya dengan kerajinan tradisional dengan berbagai bentuk, jenis, dan penyajiannya. Bentuk dan jenis makanan pada masing-masing daerah berbeda, salah satu kerajinan tradisional yang sekarang masih tetap dipelihara keberadaannya adalah kerajinan manisan pada masyarakat di Kabupaten Cianjur.

Keberadaan kerajinan tradisional makanan khas manisan pada masyarakat Kabupaten Cianjur tersebut dapat diketahui cukup unik, sebab kerajinan manisan masyarakat Cianjur ini merupakan kerajinan manisan yang sudah ada dan terpelihara secara turun temurun hingga saat ini meskipun kerajinan ini sudah mulai berkurang, oleh karena itu berangkat dari hal tersebut diatas penulis mengadakan penelitian terhadap Kerajinan Manisan Masyarakat Kabupaten Cianjur.

Kerajinan manisan masyarakat Kabupaten Cianjur di Provinsi Jawa Barat, keberadaanya masih terjaga sampai saat ini. Meskipun wilayah penyebaran pengrajin manisan khas Cianjur ini mulai berkurang tidak di semua wilayah Cianjur. Salah satu bukti dari terjaganya kerajinan manisan masyarakat Cianjur adalah banyaknya toko, kios di sepanjang jalan provinsi menuju Cianjur, baik dari arah Bandung maupun Bogor. Berkurangnya pengrajin manisan Cianjur yang hanya pada daerah tertentu saja menjadi salah satu kekhawatiran akan hilangnya budaya makanan tradisional khas Cianjur. Manisan masyarakat Cianjur memiliki khas tersendiri yang menyebabkan begitu terkenalnya makanan ini.

\section{B. HASIL BAHASAN}

Kabupaten Cianjur terletak di tengah Provinsi Jawa Barat, berjarak $65 \mathrm{~km}$ dari 
ibu kota Provinsi Jawa Barat (Bandung) dan $120 \mathrm{~km}$ dari ibu kota Negara (Jakarta). Secara Astronomis Kabupaten Cianjur terletak di antara $106^{\circ} 42$ sampai $107^{\circ} 25$ bujur timur dan $6^{\circ} 21$ sampai $7^{\circ} 32$ lintang selatan, dengan batas wilayah yaitu:

- sebelah utara berbatasan dengan wilayah Kabupaten Bogor dan Kabupaten Purwakarta;

- sebelah timur berbatasan dengan wilayah Kabupaten Bandung, Kabupaten Bandung Barat dan Kabupaten Garut;

- sebelah selatan berbatasan dengan Samudera Indonesia;

- dan di sebelah barat berbatasan dengan wilayah Kabupaten Sukabumi.

Secara umum Cianjur beriklim tropis, dengan pengaruh angin sangat besar, sehingga terdapat pergantian musim, yakni musim kemarau dan musim penghujan, curah hujan pertahunnya ratarata berkisar antara 2.500 milimeter sampai 4000 milimeter dengan jumlah hari hujan 150 hari per tahun. Adapun suhu udara Kabupaten Cianjur berkisar antara 15 derajat celsius. Suhu terendah terjadi di Cianjur bagian utara dan suhu tertinggi terjadi di Cianjur bagian selatan.

Secara geografis wilayah Kabupaten Cianjur terbagi ke dalam tiga bagian yaitu: Cianjur Bagian Utara, Tengah dan Selatan. Cianjur utara yang merupakan dataran tinggi di kaki Gunung Gede meliputi daerah puncak dan Cipanas. Ketinggian daerah puncak 1.450 meter di atas permukaan laut. Daerah ini dari kota Cianjur berjarak lebih kurang 1,5 kilometer. Kecamatan yang masuk ke wilayah ini adalah: Kecamatan Cibeber, Bojongpicung, Ciranjang, Karangtengah, Cianjur, Warungkondang, Cugenang, Pacet, Mande, Cikalongkulon, Sukaluyu, Cilaku dan Sukaresmi. Cianjur bagian tengah, merupakan daerah yang berbukitbukit kecil dengan keadaan struktur tanahnya labil sehingga sering terjadi tanah longsor. Dataran lainnya terdiri atas area perkebunan dan persawahan. Kecamatan yang masuk ke daerah ini adalah:
Kecamatan Tanggeung, Pagelaran, Kadupandak, Takokak, Sukanagara dan Campaka. Sedangkan Cianjur bagian selatan, merupakan dataran rendah yang berbukit-bukit kecil yang diselingi pegunungan yang melebar sampai ke daerah pantai Samudra Indonesia. Tanahnya labil dan sering terjadi longsor. Terdapat area perkebunan dan persawahan tetapi tidak begitu luas. Kecamatan yang masuk wilayah ini adalah: Kecamatan Agrabinta, Sindangbarang, Cidaun, Naringgul dan Cibinong.

Kabupaten Cianjur terletak di kaki Gunung Gede dengan ketinggian sekitar 450 meter di atas permukaan laut dan terendah sekitar 7 meter di atas permukaan laut. Bagian lainnya berupa perkebunan dan persawahan. Menurut Van Bamelen yang berkebangsaan Belanda, lokasi Kabupaten Cianjur termasuk zona Bandung, yang secara geografis wilayah ini terbagi menjadi tiga bagian yaitu:

- Cianjur bagian utara, merupakan dataran tinggi terletak di kaki Gunung Gede dan Gunung Pangrango yang menjadi sumber mata air bagi banyak sungai, antara lain Citarum, dengan anak-anak sungainya Cisokan, Cikundul, Ciranjang, Cidamar, Cisadea, dan Cilaki. Dengan curah hujan rata-rata 2.825 per tahun, maka daerah ini cocok dijadikan areal perkebunan dan pesawahan.

- Cianjur bagian tengah merupakan daerah berbukit-bukit. Struktur tanahnya labil karena terletak pada jalur gempa bumi dari wilayah Kabupaten Sukabumi bagian selatan, di samping itu daerah ini sering terjadi tanah longsor. Selain itu, daerah lainnya terdiri atas areal perkebunan dan areal pesawahan yang digunakan sebagai lahan pertanian terutama padi.

- Cianjur bagian selatan merupakan dataran yang terdiri atas bukit-bukit kecil diselingi pegunungan-pegunungan yang melebar ke samudera Hindia. Sebagaimana daerah lainnya, Cianjur bagian selatan ini merupakan daerah 
yang tanahnya labil dan sering terjadi longsor dan gempa bumi, begitu juga sebagian areal tanahnya digunakan sebagai arel perkebunan dan pesawahan.

Kepadatan penduduk Kabupaten Cianjur pada tahun 2005 sekitar 548,94 jiwa per $\mathrm{km}^{2}$. laju pertumbuhan penduduk Kabupaten Cianjur ini tidak merata, terlihat bahwa sekitar $63,90 \%$ penduduk Kabupaten Cianjur terkonsentrasi di bagian utara, $19,19 \%$ mendiami berbagai kecamatan di bagian tengah dan sisanya sebanyak $17,12 \%$ berada di berbagai kecamatan di bagian selatan Kabupaten Cianjur.

Kepadatan penduduk di kecamatankecamatan wilayah utara jauh lebih tinggi dibandingkan wilayah selatan dan tengah, dengan demikian pengembangan potensi ekonomi kecamatan-kecamatan di wilayah tengah dan selatan menghadapi kendala untuk dikembangkan, antara lain karena penduduknya masih jarang dan terpencar sehingga secara ekonomis pengembangan di wilayah tersebut kurang menguntunkan. Terjadinya kesenjangan penyebaran penduduk secara geografis dimungkinkan berkaitan erat dengan faktor daya tarik wilayah terutama dengan aspek ekonomi serta ketersediaan sarana tempat tinggal yang memadai.

Mata pencaharian penduduk Kabupaten Cianjur berada di sektor: (1) Pertanian 372.422 orang, (2) Industri 17.671 orang, (3) Perdagangan 109.965 orang, (4) Jasa-jasa 21.891 orang, (5) sektor lain 87.535 orang (Badan Statistik Pusat Kabupaten Cianjur, 2011). Sebagaimana daerah beriklim tropis, wilayah Cianjur Utara tumbuh subur tanaman sayuran, teh dan tanaman hias. Di Wilayah Cianjur Tengah tumbuh dengan baik tanaman padi, kelapa dan buahbuahan. Sedangkan di wilayah Cianjur Selatan tumbuh tanaman palawija, perkebunan teh, karet, aren, cokelat, kelapa serta tanaman buah-buahan. Sebagai daerah agraris yang pembangunannya bertumpu pada sektor pertanian, Kabupa- ten Cianjur merupakan salah satu daerah swasembada padi. Produksi padi per tahun sekitar 625.000 ton. Produksi pertanian padi terdapat hampir di seluruh wilayah Cianjur, kecuali di Kecamatan Pacet dan Sukanagara yang didominasi oleh tanaman hias dan tanaman sayuran yang di pasok ke daerah Jabodetabek. Potensi perkebunan di Kabupaten Cianjur cukup besar ada sekitar 19,4 persen dari seluruh luas merupakan area perkebunan. Selama ini dikelola oleh Perkebunan Besar Negara (PBN) seluas 10.709 hektar, Perkebunan Besar Swasta (PBS) sekitar 20.174 hektar dan Perkebunan Rakyat (PR) seluas 37.167 hektar.

Cianjur memiliki filosofi yang sangat bagus, yakni ngaos, mamaos dan maenpo yang mengingatkan tentang 3 (tiga) aspek keparipurnaan hidup. Ngaos adalah tradisi mengaji yang mewarnai suasana dan nuansa Cianjur dengan masyarakat yang dilekati dengan ke beragamaan. Citra sebagai daerah agamis ini konon sudah terintis sejak Cianjur ada dari ketiadaan yakni sekitar tahun 1677 dimana tatar Cianjur ini dibangun oleh para ulama dan santri tempo dulu yang gencar mengembangkan syiar Islam. Itulah sebabnya Cianjur juga sempat mendapat julukan gudang santri dan kyai. Bila di tengok sekilas sejarah perjuangan di tatar Cianjur jauh sebelum masa perang kemerdekaan, bahwa kekuatan-kekuatan perjuangan kemerdekaan pada masa itu tumbuh dan bergolak pula di pondokpondok pesantren. Banyak pejuangpejuang yang meminta restu para kyai sebelum berangkat ke medan perang. Mereka baru merasakan lengkap dan percaya diri berangkat ke medan juang setelah mendapat restu para kyai. Mamaos adalah seni budaya yang menggambarkan kehalusan budi dan rasa menjadi perekat persaudaraan dan kekeluargaan dalam tata pergaulan hidup. Seni mamaos tembang Sunda Cianjuran lahir dari hasil cipta, rasa dan karsa Bupati Cianjur R. Aria Adipati Kusumahningrat yang dikenal dengan sebutan Dalem Pancaniti. Ia menjadi 
pupuhu (pemimpin) tatar Cianjur sekitar tahun 1834-1862.

Seni mamaos ini terdiri dari alat kecapi indung (Kecapi besar dan Kecapi rincik (kecapi kecil) serta sebuah suling yang mengiringi panembanan atau juru. Pada umumnya syair mamaos ini lebih banyak mengungkapkan puji-pujian akan kebesaran Tuhan dengan segala hasil ciptaanNya. Sedangkan maenpo adalah seni diri pencak silat yang menggambarkan keterampilan dan ketangguhan. Pencipta dan penyebar maenpo ini adalah $\mathrm{R}$. Djadjaperbata atau dikenal dengan nama R. H. Ibrahim aliran ini mempunyai ciri permainan rasa yaitu sensitivitas atau kepekaan yang mampu membaca segala gerak lawan ketika anggota badan saling bersentuhan. Dalam maenpo dikenal ilmu Liliwatan (penghindaran) dan Peupeuhan (pukulan).

Apabila filosofi tersebut diresapi, pada hakekatnya merupakan simbolsimbol rasa keberagaman, kebudayaan dan kerja keras. Dengan keberagaman sasaran yang ingin dicapai adalah terciptanya keimanan dan ketaqwaan masyarakat melalui pembangunan akhlak yang mulia. Dengan kebudayaan, masyarakat Cianjur ingin mempertahankan keberadaannya sebagai masyarakat yang berbudaya, memiliki adab, tatakrama dan sopan santun dalam tata pergaulan hidup. Dengan kerja keras sebagai implementasi dari filosofi maenpo, masyarakat Cianjur selalu menunjukan semangat keberdayaan yang tinggi dalam meningkatkan mutu.

Seni tradisional yang terdapat di Kabupaten Cianjur sampai sekarang masih dilestarikan keberadaannya seperti; tembang cianjuran, ketuk tilu jaipongan, kecapian, pencak silat, angklung buncis, calung, seni gondang, seni dulag, dan seni wayang golek. Seni tembang cianjuran yang merupakan gaya tembang khas daerah Cianjur dengan pengiring kecapi dan suling bertempo bebas dengan syair berpola pupuh. Cianjuran ini muncul atas prakarsa dalam Pancaniti, bupati Cianjur, yang diteruskan oleh putranya R. Alibasah.
Pada masa ini, penyebaran tembang Cianjuran makin meluas, dan tembangtembangnya sangat digemari oleh kaum muda pada jamannya karena bersifat romantis.

Sistem kekerabatan orang Sunda pada umumnya dan masyarakat Cianjur pada khususnya, dipengaruhi oleh keyakinan beragama dan adat istiadat secara turun temurun, hal ini tercermin dari ungkapan yang menyebutkan bahwa "ulah munjung ka gunung ulah muja ka sagara, tapi kudu munjung ka indung jeung muja ka bapa". Ungkapan tersebut mencerminkan eratnya kekerabatan, di samping wajib patuhnya seorang anak kepada kedua orang tuanya, masyarakat Sunda menyebut kekerabatan tersebut dengan "bondoroyot" terutama sebutan dalam kerabat keluarga batih.

Agama Islam merupakan agama yang dianut mayoritas penduduk Kabupaten Cianjur. Sementara pemeluk agama lain seperti: Kristen, Hindu, Budha, dan Konghucu merupakan bagian kecil yang dianut penduduk Kabupaten Cianjur. Jumah pemeluk agama Islam tercatat 1.379.606 orang, dan sisanya penduduk yang beragama Katholik 3.743 orang, Protestan 2.391 orang, Hindu 251 orang, Budha 2008 orang, dan Konghucu berjumlah 1.174 orang. Dari jumlah pemeluk agama-agama tersebut tentunya diimbangi pula dengan sarana pribadatan yang tersedia di Kabupaten Cianjur. Hal ini dibuktikan dengan tersedianya 3.386 masjid, dan 1.126 mushola bagi pemeluk agama Islam. Selain sarana peribadatan tersebut terdapat pula; tajug, yaitu bangunan kecil yang didirikan di atas kolam atau pinggiran sungai untuk melakukan salat atau tempat beristirahat usai membajak tanah.Tajug tersebut ditemukan di wilayah Kabupaten Cianjur terutama di daerah-daerah pedesaan yang mayoritas panduduknya bermata pencaharian sebagai petani.

Adapun jumlah tempat ibadat agama Kristen, Hindu, Budha, dan Konghucu di Kabupaten Cianjur, terdapat 22 buah Gereja, 2 buah Vihara, 2 buah Pura, dan 1 
buah Klenteng. Tempat-tempat peribadatan tersebut pada umumnya didirikan di lokasi-lokasi strategis yang mudah dijangkau oleh pemeluknya, seperti di sepanjang jalan raya dan pusat kota Kabupaten Cianjur dan sebagian lagi terdapat di kotakota kecamatan dan di perkampungan penduduk.

Kehidupan umat beragama bagi masyarakat Cianjur dirasakan bertambah mantap. Hal itu didasari oleh kesadaran masing-masing pemeluk agama untuk melaksanakan ibadahnya dengan tenang dan damai. Bagi umat Islam umumnya, mereka taat menjalankan kewajibankewajiban agama seperti; salat lima waktu, puasa, dan menunaikan ibadah haji ke tanah suci Mekah bagi mereka yang mampu. Suasana kehidupan keagamaan tersebut dapat dilihat dalam berbagai kegiatan yang tidak didominasi oleh orang tua, melainkan anak-anak dan generasi muda, hal ini nampak pada hari-hari biasa yang telah menjadi kegiatan rutin.

\section{Kerajinan Manisan di Kabupaten Cianjur}

Manisan Cianjur muncul pada akhir tahun lima puluhan atau awal enampuluhan, bersamaan dengan meluapnya produksi buah dari sekitar Cianjur, akibat terganggunya distribusi buah dan palawija menyusul "nasionalisasi" perusahaanperusahaan dagang Belanda oleh Pemerintah saat itu. Membludaknya buahbuahan yang membusuk itu, memunculkan ide mengawetkan yang sudah dimiliki oleh para perantau Cina dari leluhurnya di daratan Cina. Melalui serangkaian proses yang cukup panjang, buah-buahan yang semula mudah membusuk (jamur atau kapang) karena sinar matahari atau kesalahan pada saat panen menjadi lebih awet. Sekali pun ilmu mengawetkan ini berasal dari Cina, namun rasa (taste) nya jauh berbeda dengan aslinya di sana. Rasa manisan Cianjur jauh lebih manis yang dikombinasikan dengan rasa masam dari buah, menimbulkan rasa khas Cianjur. Ciri khas manisan Cianjur yang berbeda dengan manisan dari daerah lain, adalah cara para pedagang memajang dagangannya, yakni dengan menempatkan dalam deretan bejana bekas botol yang menjadi hiasan tersendiri yang menarik. Awalnya hanya buah pala saja yang dibuat, namun kini buah telah biasa dijadikan manisan, dari salak sampai ceremai. Menurut salah satu generasi perintis manisan Cianjur dari keluarga Ny. Tan, manisan Cianjur mulai terkenal sejak dikunjungi oleh istri Presiden Soekarno. Saat ini generasi perintis manisan Cianjur, generasi ke-3 dan ke-4 masih mempertahankan keaslian manisan Cianjur dengan tidak menggunakan bahan pengawet.

Manisan yang kemudian menjadi makanan olahan masyarakat Cianjur khususnya wilayah kota dan sekitarnya, menjadi salah satu dari mata pencaharian yaitu dengan memproduksi dan menjualnya. Manisan Cianjur dapat ditemukan di sepanjang jalan Bandung-Cianjur, CianjurJakarta, Bogor, Sukabumi. Toko-toko sepanjang jalan tersebut di atas menjadi salah satu pemandangan yang khas Kabupaten Cianjur.

\section{Jenis Manisan Cianjur}

Manisan buah adalah buah-buahan yang direndam dalam larutan gula selama beberapa waktu. Manisan biasanya dimakan sebagai hidangan pelengkap untuk merangsang nafsu makan. Teknologi membuat manisan merupakan salah satu cara pengawetan makanan yang sudah diterapkan sejak dahulu kala. Perendaman manisan akan membuat kadar gula dalam buah meningkat dan kadar airnya berkurang. Keadaan ini akan menghambat pertumbuhan mikroba perusak sehingga buah akan lebih tahan lama. Teknologi yang berkembang saat ini memungkinkan manisan dapat bertahan dalam jangka waktu yang cukup lama. Pada saat ini telah berkembang berbagai jenis manisan yang berkembang di masyarakat Kabupaten Cianjur, yaitu: Manisan Basah, yaitu manisan yang diperoleh setelah penirisan buah dari larutan gula. Manisan basah mempunyai kandungan air yang lebih 
banyak dan penampakan yang lebih menarik karena serupa dengan buah aslinya. Manisan basah biasanya dibuat dari buah yang keras. Contoh buah untuk manisan basah adalah: kolangkaling, mangga, kedondong, salak, pepaya, ceremai, belimbing, jambu biji, canar, rumput laut, bengkuang, dan nangka.

Manisan Kering, yaitu manisan yang diperoleh setelah buah ditiriskan kemudian dijemur sampai kering. Manisan kering ini memiliki daya simpan yang lebih lama, kadar air yang lebih rendah, dan kadar gula yang lebih tinggi. Manisan kering biasanya dibuat dari buah yang teksturnya lunak seperti: kedondong, Asamjawa, Bengkuang, dan pala.

Manisan Sayuran, manisan ini merupakan manisan yang relatif baru dikembangkan oleh masyarakat Cianjur. Manisan sayuran yaitu masian yang terbuat dari bahan sayuran termasuk ke dalam jenis manisan basah. Sayuran yang biasa digunkan untuk manisan sayuran ini seperti, sawi dan cabai. Manisan sayuran ini berpusat di wilayah Warung Kondang. Manisan jenis ini juga mulai ramai dipasarkan.

Manisan Kelapa (Nata De Coco), yaitu manisan yang terbuat dari bahah air kelapa yang melalui proses fermentasi. Manisan kelapa yang lebih terkenal dengan istilah nata de coco ini mulai dirintis di Kabupaten Cianjur sekitar tahun 1983. Manisan ini berpusat di wilayah kota Cianjur. Manisan kelapa ini banyak dipasarkan.

\section{Teknik Pembuatan Manisan}

Manisan cianjur sejak dahulu memiliki daya tarik tersendiri hingga saat ini, tentunya hal itu tidak terlepas dari sistem produksi yang berkelanjutan. Proses produksi atau pembuatan manisan cianjur sendiri terus berkembang seiring dengan perkembangan teknologi tanpa mengurangi kulaitas dari manisan cianjur itu sendiri. Dilihat dari produksi tersebut, maka dapat diurai dalam beberapa bagian, yaitu:

\section{a. Manisan Buah Mangga}

Manisan jenis buah mangga ini banyak terdapat di pasaran, baik wilayah Cianjur maupun untuk keluar Cianjur. Proses produksi atau pembuatan manisan buah mangga adalah sebagai berikut:

\section{Bahan:}

1. Buah mangga yang masih segar/masih mengkal $10 \mathrm{~kg}$

2. Gulapasir $5 \mathrm{~kg}$

3. Kapur sirih 1 sdt

4. Natriumbenzoat $4 \mathrm{sdt}$

5. Garam dapur 15 gr

6. Panili $2 \mathrm{sdm}$

7. Air matang $7 \mathrm{ltr}$

Alat: Pisau, Saringan, Baskom, Kompor

\section{Cara Pembuatan:}

1. Kupas buah mangga kemudian dicuci dan potong sesuai dengan ukuran yang dikehendaki.

2. Rendam dalam air garam panas (50 gr /1 ltr air) selama 2 jam lalu tiriskan

3. Kemudian Rendam dalam air kapur (1 sdm kapur sirirh dalam 1,5lt air) selama 1 atau 2 hari lalu tiriskan

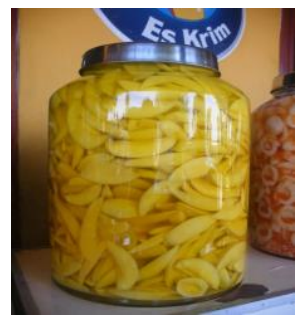

Manisan buah yang sudah dikemas

4. Masukkan gula pasir dalam 2,5 lt air, aduk sampai rata. Tambahkan garam dan natriumbenzoat lalu panaskan hingga mendidih,

5. Masukan potongan buah ke dalam larutan gula yang sedang mendidih sampai buah tersebut setengah matang. Angkat panci dari kompor dan diamkan (rendam) 1 malam, lalu tiriskan,

6. Panaskan air gula sisa penirisan dan tambahkan vanili lalu masukkan lagi potongan buah tersebut. Angkat panci dari kompor dan diamkan satu malam. Untuk mendapatkan manisan basah, 
tiriskan buah, sedangkan air gula sisa penirisan terakhir dapat diolah lebih lanjut dengan menambahkan $1 / 2 \mathrm{~kg}$ gula. Panaskan sampai kental kemudian didinginkan. Setelah dingin siap dikemas sebagai hasil samping sirup buah.

7. Manisan buah mangga siap dikonsumsi dan dikemas dan dipasarkan.

Proses pembuatan manisan buah mangga ini membutuhkan waktu 4-5 hari, manisan hasil produksi ini dapat bertahan cukup lama antara 1-2 bulan. Manisan buah mangga juga dapat diproduksi dengan rasa yang pedas. Prosesnya sama dengan proses pembuatan manisan mangga, hanya ditambahkan dengan cabe merah yang sudah dihaluskan.

\section{b. Manisan Buah Kedondong}

Manisan buah kedongdong cara pembuatannya sama dengan pembuatan manisan buah mangga, hanya bahan bakunya saja yang diganti dengan kedondong. tapi tidak menutup kemungkinan setiap tempat produksi memiliki resep rahasia tersendiri. Manisan kedongdong juga dapat dibuat dengan rasa pedas.
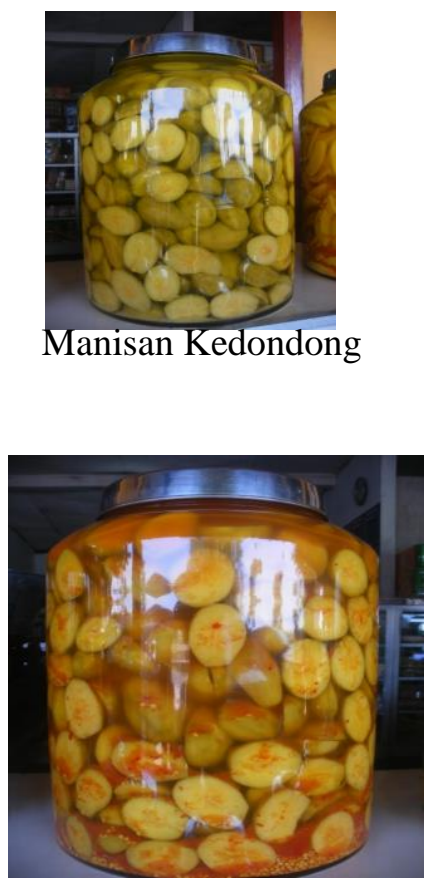

Manisan Kedondong pedas

\section{c. Manisan Buah Salak}

Manisan buah salak cara pembuatannya sama dengan pembuatan manisan buah mangga, hanya bahan bakunya saja yang diganti dengan salak. tapi tidak menutup kemungkinan setiap tempat produksi memiliki resep rahasia tersendiri. Manisan Salak juga dapat dibuat dengan rasa pedas.

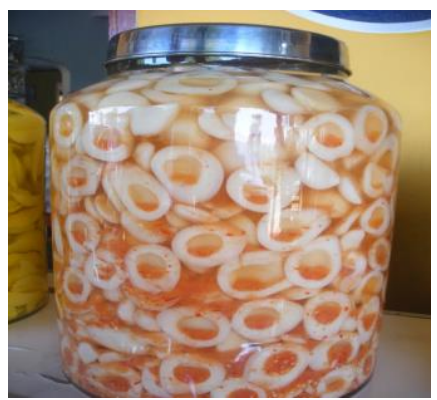

Manisan Salak Pedas

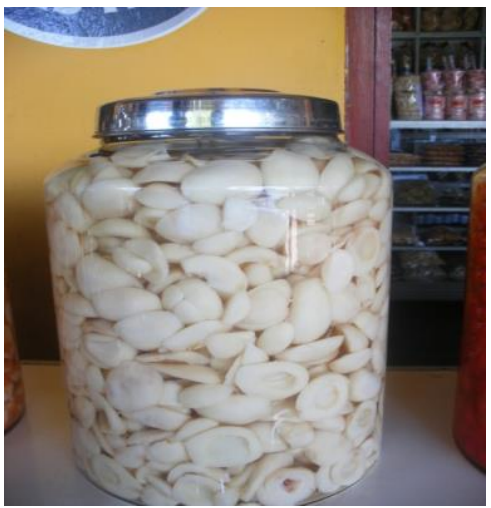

Manisan Salak

\section{d. Manisan Jambu Biji}

Manisan buah jambu biji cara pembuatannya sama dengan pembuatan manisan buah mangga, hanya bahan bakunya saja yang diganti dengan jambu biji. tapi tidak menutup kemungkinan setiap tempat produksi memiliki resep rahasia tersendiri. 


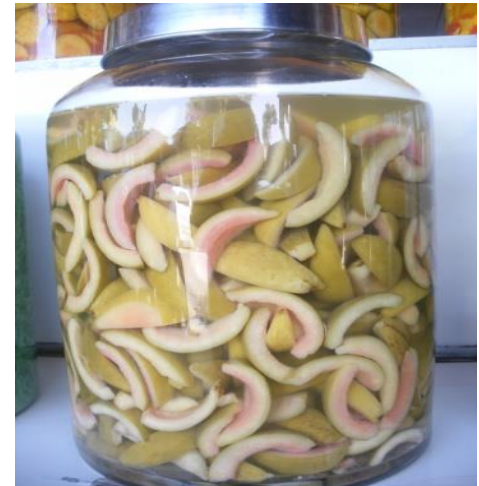

Manisan Jambu Biji

\section{e. Manisan Bengkuang}

Manisan bengkuang cara pembuatannya sama dengan pembuatan manisan buah yang lain, hanya bahan bakunya saja yang diganti dengan Bengkuang. Tapi tidak menutup kemungkinan setiap tempat produksi memiliki resep rahasia tersendiri. Manisan Bengkuang juga dapat dibuat dengan rasa pedas.

\section{f. Manisan Kolangkaling}

Manisan Kolangkaling cara pembuatannya sama dengan pembuatan manisan buah yang lain, hanya bahan bakunya saja yang diganti dengan Kolangkaling Tapi tidak menutup kemungkinan setiap tempat produksi memiliki resep rahasia tersendiri.

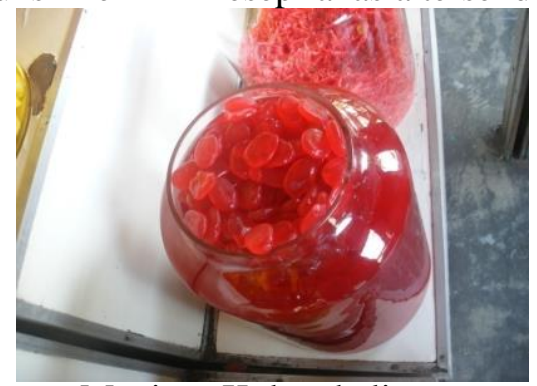

Manisan Kolangkaling

\section{g. Manisan Canar}

Manisan Canar cara pembuatannya sama dengan pembuatan manisan buah yang lain, hanya bahan bakunya saja yang diganti dengan Canar. Tapi tidak menutup kemungkinan setiap tempat produksi memiliki resep rahasia tersendiri.

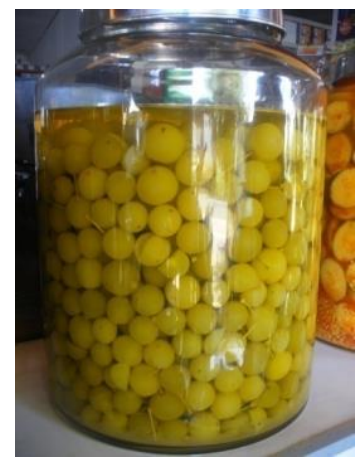

\section{Manisan Canar}

\section{h. Manisan Pala}

Sebagai manisan perintis, manisan pala ini selalu ada dipasaran. Manisan pala cara pembuatannya sama dengan pembuatan manisan buah yang lain, hanya bahan bakunya saja yang diganti dengan pala. Tapi tidak menutup kemungkinan setiap tempat produksi memiliki resep rahasia tersendiri. Manisan pala ini selain dibuat manisan basah, juga dapat dibuat manisan kering.

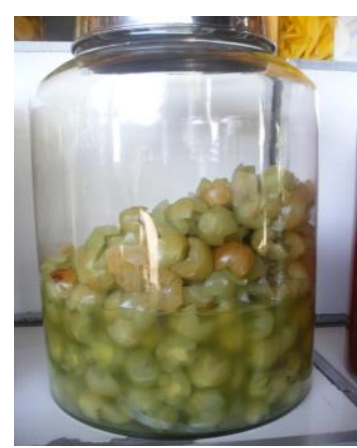

Manisan Pala

\section{i. Manisan Rumput Laut}

Manisan rumput laut cara pembuatannya sama dengan pembuatan manisan buah yang lain, hanya bahan bakunya saja yang diganti dengan rumput laut. Tapi tidak menutup kemungkinan setiap tempat produksi memiliki resep rahasia tersendiri. Manisan rumput laut ini selain dibuat manisan basah, juga dapat dibuat, manisan kering. 


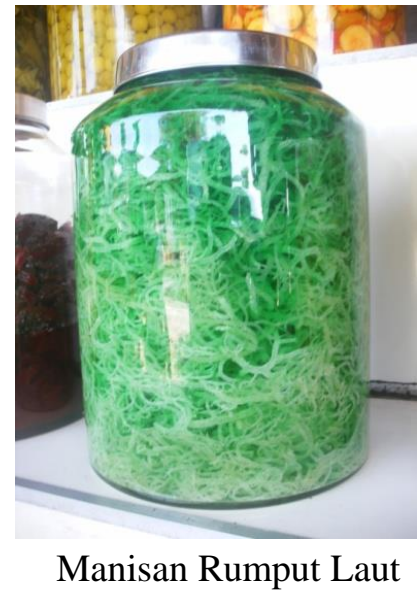

\section{j. Manisan Belimbing}

Manisan Belimbing cara pembuatannya sama dengan pembuatan manisan buah yang lain, hanya bahan bakunya saja yang diganti dengan Belimbing. Tapi tidak menutup kemungkinan setiap tempat produksi memiliki resep rahasia tersendiri.

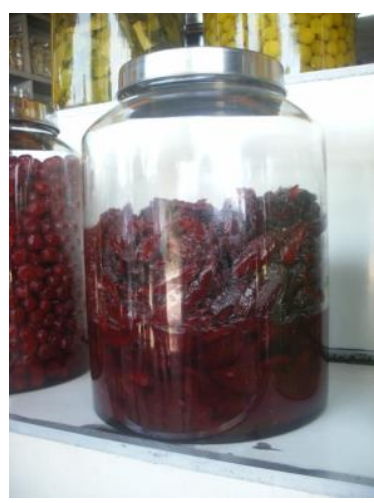

Manisan Belimbing

\section{k. Manisan Ceremai}

Manisan Ceremai cara pembuatannya sama dengan pembuatan manisan buah yang lain, hanya bahan bakunya saja yang diganti dengan Ceremai. Tapi tidak menutup kemungkinan setiap tempat produksi memiliki resep rahasia tersendiri.

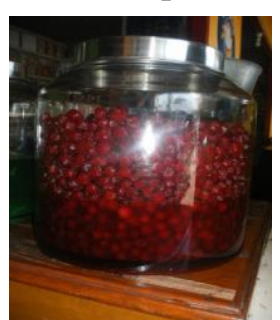

Manisan Ceremai

\section{Manisan Pepaya}

Manisan Pepaya cara pembuatannya sama dengan pembuatan manisan buah yang lain, hanya bahan bakunya saja yang diganti dengan Pepaya. Hanya manisan papaya ini sifatnya kering, jadi setelah ditiriskan papaya kemudian dijemur kurang lebih sepertiga hari. Tapi tidak menutup kemungkinan setiap tempat produksi memiliki resep rahasia tersendiri.

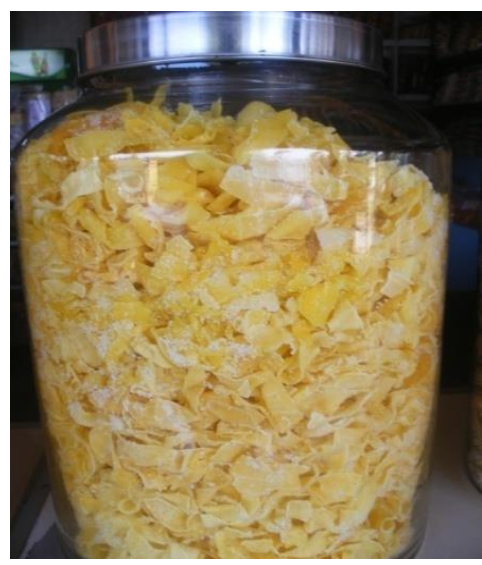

Manisan Pepaya

\section{m. Manisan Asam}

Manisan Asam cara pembuatannya sama dengan pembuatan manisan buah yang lain, hanya bahan bakunya saja yang diganti dengan Asam. Hanya manisn papaya ini sifatnya kering, jadi setelah ditiriskan asam kemudian dijemur kurang lebih sepertiga hari. Tapi tidak menutup kemungkinan setiap tempat produksi memiliki resep rahasia tersendiri.

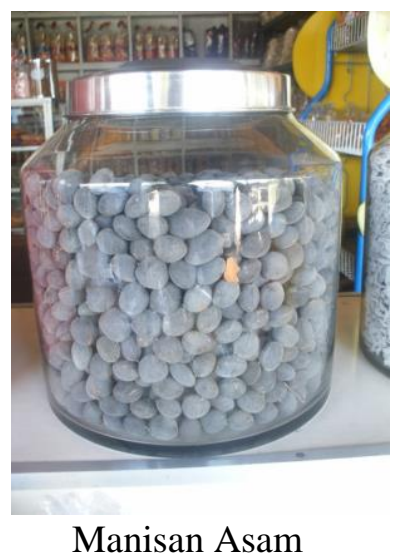

Manisan Asam 


\section{n. Manisan Sawi (Sayuran)}

Manisan Sawi merupakan manisan jenis sayuran, manisan jenis ini relative baru dikembangkan oleh masyarakat Cianjur. Proses pembuatannya hampir sama dengan pembuatan manisan buah, hanya bahan bakunya saja yang diganti dengan sayuran, dalam hal ini sawi. Tapi tidak menutup kemungkinan setiap tempat produksi memiliki resep rahasia tersendiri.

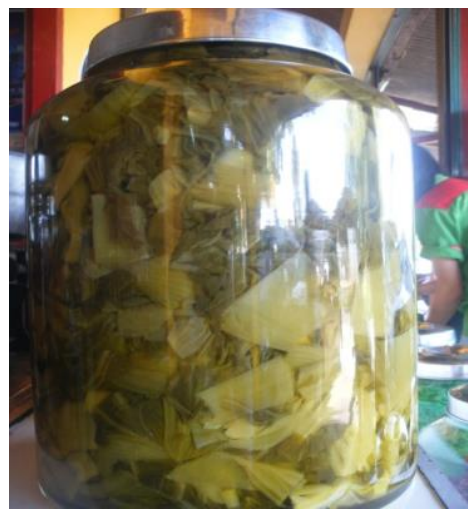

Manisan Sayuran Sawi

\section{o. Manisan Kelapa atau Nata De Coco}

Untuk manisan kelapa cara pembuatannya berbeda dengan manisn buah lainnya. Berikut cara pembuatan manisan kelapa ini adalah sebagai berikut:

1) Bahan:

- 100 ltr air kelapa

- 100 gr $\mathrm{CH} 2 \mathrm{O}$

- Cuka makan 150 cc

- Gula pasir 500 gr

2) Proses fermentasi, sebelumnya air kelapa sudah dimasak hingga mendidih dengan bahan yang telah dituliskan pada poin pertama. Kemudian baru proses fermentasi lebih kurang selama 8 hari.

3) Proses netralisasi minimal selama 2 hari

4) Setelah proses netralisasi manisan dapat dikonsumsi dan dapat diolah untuk berbagai jenis masakan. Atau dapat dikemas untuk dipasarkan.

Demikian cara pembuatan manisan kelapa yang dilaksanakan oleh pengrajin di wilayah Cianjur kota. Mungkin setiap tempat produksi memiliki resep dan bahan tambahan tersendiri.

\section{Bahan Baku}

Olahan Manisan Cianjur yang makin berkembang tidak terlepas dari ketersediaan bahan baku yang memadai. Semua olahan manisan Cianjur baik itu buah-buahan, sayuran dan kelapa memerlukan bahan baku yang tidak sedikit, diperlukan stok yang cukup banyak. Sebagian besar pengrajin olahan manisan Cianjur memperoleh bahan baku dari wilayah Cianjur sendiri. Bahan baku buah-buahan dibeli dari pasar-pasar yang ada di wilayah Kabupaten Cianjur, atau langsung dari petani di wilayah Cianjur. Apabila stok di Cianjur tidak ada, maka para pengrajin olahan manisan Cianjur ini biasa membeli bahan baku buah-buahan dari Pasar Induk Caringin di Kota Bandung. Atau bahkan ada beberapa pengrajin yang memiliki rekanan bahan baku buah-buahan dari wilayah Sukabumi dan Bogor.

Khusus untuk bahan baku pembuatan manisan kelapa/nata de coco, bahan baku cukup dari wilayah kota Cianjur. Biasanya bahan baku yang berupa air kelapa diperoleh dari pedagang kelapa di pasar tradisional.

\section{Tenaga Kerja}

Industri manisan yang berkembang di Kabupaten Cianjur, sejak dulu hingga sekarang sebagian besar merupakan industri rumahan yang memperkerjakan saudara dan tetangganya. Hanya sebagian kecil saja yang menggunakan jasa tenaga kerja dari luar daerah. Sebagian besar dari industri manisan merupakan industri yang diwariskan dari para leluhurnya, sehingga mereka pun dalam produksinya hanya memperkerjakan saudara, baik saudara dekat maupun saudara jauh.

\section{Pemasaran}

Olahan manisan yang telah siap dikonsumsi, biasanya dikemas dan siap dipasarkan. Pendistribusian hasil olahan manisan ini dilakukan dengan mengantar langsung ke rekan bisnis untuk wilayah yang berada di Kabupaten Cianjur. Ada pula rekanan yang menjemput hasil olahan 
ke tempat produksi. Biasanya pemasaran olahan manisan ini berada di wilayah Cianjur kota, wilayah Warung Kondang, wilayah Ciranjang wilayah Cipanas dan beberapa wilayah kecamatan Cianjur lainnya.

Untuk pendistribusian ke luar wilayah Kabupaten Cianjur, terutama ke wilayah Jawa Barat, DKI Jakarta, dan Banten biasanya diantar langsung ke tempat yang memesan. Wilayah pemasaran di daerah Jawa Barat meliputi Kabupaten Bandung Barat, Kabupaten Bandung, Kota Bandung, Kabupaten Tasikmalaya, Kabupaten Garut, Kabupaten Sumedang, Kabupaten Bogor, Kabupaten Sukabumi, Kota Sukabumi, Kota Bogor, Kabupaten Purwakarta, Kabupaten Bekasi dan Kabupaten Karawang. Untuk wilayah Banten, pemasarannya ke wilayah kabupaten dan Kota Tangerang. Sementara untuk Wilayah DKI Jakarta meliputi semua kota Di DKI Jakarta. Pendistribusian olahan manisan ke wilayah-wilayah tersebut dilakukan dalam rentang satu minggu sekali atau sesuai dengan pesanan.

Selain wilayah-wilayah di atas pemasaran olahan manisan Cianjur juga sampai ke pulau Sumatera, yaitu ke wilayah Lampung dan Bengkulu. Untuk wilayah Lampung dan Bengkulu pendistribusian dilakukan dengan cara dipaketkan. Pendistribusian dilaksanakan sesuai dengan pesanan, tetapi rata-rata bisa didistribusikan seminggu sekali.

\section{PENUTUP}

\section{Kesimpulan}

Saat ini manisan Cianjur sudah berkembang dengan pesat, jumlah buahbuahan yang dapat dijadikan manisan pun semakin banyak. Selain buah-buahan pada saat ini masyarakat Cianjur pun mengembangkan manisan sayuran. Manisan buah-buahan pun saat ini diolah dengan rasa lain yaitu pedas. Sebuah kreativitas dalam pengolahan manisan yang patut dibanggakan. Beberapa buah yang menjadi bahan baku manisan buah- buahan dan sayuran antara lain: kolangkaling, mangga, kedongdong, salak, bengkoang, asam Jawa, pala, leci, canar, pepaya, nangka, belimbing, jambu biji, ceremai, rumput laut, sawi dan cabai. Saat lagi manisan yang berkembang adalah manisan kelapa atau lebih dikenal dengan nama nata de coco. Bahan bakunya adalah air kelapa.

Manisan hasil olahan masyarakat Cianjur ini selain dipasarkan di wilayah Cianjur, juga dipasarkan ke wilayah lain seperti Tanggerang, Bandung, DKI Jakarta, Garut, Tasikmalaya hingga bengkulu dan Lampung. Manisan ini didistribusikan sesuai pesanan dari rekanan bisnis di masing-masing daerah. Biasanya minimal seminggu sekali para pengrajin olahan manisan Cianjur ini mendistribusikan hasil olahannya.

Selalu ada manfaat atau nilai yang dapat diambil hikmahnya dari tumbuh dan berkembangnya setiap kegiatan, tidak terkecuali dengan pertumbuhan kerajinan manisan Cianjur ini. manisan Cianjur yang merupakan warisan dari nenek moyang masyarakat Cianjur, dilestarikan bahkan dikembangkan oleh masyarakatnya, hal ini menjadi bukti sebagai penghormatan kepada para leluhur atau nenek moyangnya. Selain itu sistem produksi, distribusi dan pemasaran yang hampir melibatkan keluarga dan tetangga sekitarnya membuat ikatan kekeluargaan semakin kokoh. Dengan memperkerjakan saudara dan tetangga berarti telah mempererat persaudaraan dan silaturahmi sehingga kerukunan diantara mereka semakin erat.

Berkembangnya manisan Cianjur juga membuat beberapa orang bekerjasama membuat kelompok produksi, distribusi dan pemasaran. Nilai kerjasama ini sangat luar biasa dalam menumbuhkembangkan usaha dan persaudaraan. Dengan kerjasana membangun kelompok diyakini usaha akan semakin kuat dan berkembang. Dengan tumbuh dan berkembangnya olahan manisan Cianjur hingga ke daerah lain, membuat ekonomi masyarakat Cianjur yang bergelut dengan olahan manisan 
Cianjur ini menjadi meningkat. Mereka, baik yang terlibat di produksi, distribusi maupun pemasaran akan memdapatkan nilai ekonomi yang lebih dari tumbuh kembangnya usaha olahan manisan Cianjur ini

\section{Saran}

Manisan Cianjur dapat dikatakan menjadi idola bagi setiap orang yang berkunjung ke wilayah Kabupaten Cianjur. Tetapi olahan manisan ini perlu pengembangan inovasi agar lebih banyak tawaran untuk dipasarkan. Misalnya dalam pengembangan bahan baku buah-buahan, dapat ditambah dengan buah-buahan yang saat ini belum di produksi. Misalnya dengan membuat manisan anggur, lengkeng dan buah-buahan lainnya yang mungkin dapat dibuat manisan. Sama halnya dengan sayuran, perlu dibuat tambahan manisan dengan variasi jenis sayuran lain diluar sawi dan cabai. Bukankah masih banyak sayuran yang mungkin dapat dibuat manisan sayuran. Dengan tambahan ragan jenis buah, diharapkan pasar manisan Cianjur akan lebih berkembang. Selain tambahan jenis buah dan sayuran, mungkin perlu inovasi bentuk potongan buah-buahan agar lebih menarik. Dan mungkin perlu inovasi lain yang memungkinkan rasanya lebih lezat.

Selain itu perlu dukungan yang lebih nyata dari pemerintah daerah, agar olahan manisan ini dapat menjadi bentuk dari warisan budaya yang terus lestari. Dengan berkembangnya olahan manisan saat ini, menjadi modal besar bagi pemerintah untuk membantu agar olahan manisan Cianjur ini semakin berkembang, bukan hal yang tidak mungkin manisan Cianjur dapat di expor ke luar negeri dan hal ini akan menjadi kebanggaan tersendiri bagi masyarakat Kabupaten Cianjur khususnya dan bangsa Indonesia umumnya.

\section{DAFTAR SUMBER}

1.Buku

Denny Natamihardja, Bunga Rampai dari Cianjur, Cianjur Dinas Pendidikan
Cianjur dan Lembaga Kebudayaan Cianjur, 2008.

Rieza D Dienaputra, dkk, Sejarah Lokal Cianjur, Bandung : Minor Books, 2006.

Sejarah Daerah Jawa Barat. 1984. Proyek Inventarisai dan Dokumentasi Kebudayaan Daerah, Departemen Pendidikan dan Kebudayaan.

Mumuh Muhsin Z,.M. 2010. Bunga Rampai Sejarah dan Kebudayaan. Kementerian Kebudayaan dan Pariwisata. BPSNT. Bandung

Yetti Herayati, dkk. 1986. Makanan: Wujud Variasi dan Fungsi Serta Cara Penyajiannya Pada Orang Sunda Daerah Jawa Barat. Bandung: Departemen Pendidikan dan Kebudayaan

\section{Internet}

http://www.Cianjurcybercity.com/2009/02/ $\underline{20 /}$

http://www.cianjur.Co.Id 